УДК $376.1+65.014 .12+37.013 .8]: 004(045)$

Дегтяренко Тетяна Миколаївна

доцент, доктор педагогічних наук, професор кафедри корекційної та інклюзивної освіти Сумський державний педагогічний університет імені А. С. Макаренка, м. Суми, Україна

t.dehtyarenko@gmail.com

\title{
ПОШИРЕННЯ ІДЕЙ УПРОВАДЖЕННЯ ІНФОРМАЦИЙНО- КОМУНІКАЦІЙНИХ ТЕХНОЛОГІЙ У СИСТЕМУ СПЕЦІАЛЬНОЇ ОСВІТИ
}

\begin{abstract}
Анотація. У статті досліджено деякі аспекти впровадження в систему спеціальної освіти ідей використання сучасних інформаційних технологій. Висвітлюються напрямки сучасних наукових досліджень у спеціальній педагогіці з проблеми впровадження інформаційних технологій. Розглянуто теоретичні і практичні здобутки у використанні комп’ютерних i хмарних технологій на інституціональному рівні. 3'ясовано сутність і можливості розвитку інформатизованого середовища в межах спеціальної школи й безпосередньо можливості використання новітніх інформаційних технологій під час навчання розумово відсталих дітей. Обгрунтовано доцільність формування базового рівня компетентності розумово відсталих школярів у галузі інформатики. Визначено перспективи подальших наукових досліджень у цій галузі. Зазначено, що їх предметним полем має стати процес розвитку інформатизованого середовища на рівні спеціальної школи.
\end{abstract}

Ключові слова: розумово відсталі учні; спеціальна освіта; інформаційні технології; комп'ютерні технології; хмарні технології.

\section{1. ВСТУП}

На сучасному етапі розвитку людства незаперечним $\epsilon$ твердження щодо необхідності розвитку інформаційного суспільства. У нашій країні питання інформатизації і широкого використання інформаційних технологій неодноразово порушувалося як на найвищому державному, так і науковому рівні. Для створення умов для їх упровадження в Україні був прийнятий Закон України «Про Основні засади розвитку інформаційного суспільства в Україні на 2007-2015 роки» [8] та інші нормативно-правові акти, у яких визначено стратегію розвитку інформаційного суспільства в Україні і план заходів з виконання цього завдання. Упровадження в життя сучасних підходів до розвитку інформаційного суспільства вимагає від системи спеціальної освіти перебудови з урахуванням вимог суспільства.

Аналіз актуальних досліджень. У процесі вивчення проблеми було встановлено, що основну частину досліджень проблеми впровадження інформаційних технологій у систему освіти присвячено вивченню доцільності застосування інформаційнокомунікаційних технологій (далі - IКТ), зокрема, комп'ютерних і хмарних технологій, у роботі загальноосвітніх навчальних закладів. Науковці вивчають як можливості впровадження цих технологій у професійну діяльність адміністрації і педагогічного персоналу навчального закладу, так і можливості їх застосування під час навчання учнів.

Питання використання хмарних технологій у навчальному середовищі широко висвітлювали у своїх працях такі дослідники як В. Ю. Биков, Л. А. Карташова, В. Г. Кремінь, О. Г. Кузьминська, С. Г. Литвинова, Н. В. Морзе, О. М. Спірін, А. М. Стрюк, М. П. Шишкіна та ін.; питання застосування комп'ютерних технологій у роботі $з$ дітьми $з$ типовим розвитком: Р. С. Гуревич, Ю. О. Жук, В. М. Добряги, В. М. Симонова, В. А. Лецко та ін. 
Аналіз змісту наукових публікацій з проблеми дослідження в галузі спеціальної педагогіки дозволив нам виокремити наукові публікації, які присвяченіу висвітленню особливостей упровадження інформаційно-комунікаційних технологій в систему спеціальної освіти. О. Василенко, О. Гончарова, Г. Загурська, В. Засенко, А. Колупаєва, О. Качуровська, Н. Кравець, О. Кукушкіна, О. Легкий, М. Малофеєв, Б. Мороз, С. Миронова, В. Овсяник М. Сметанський М. Шеремет та ін. у своїх працях визначили роль і місце ІКТ в системі спеціальної освіти і довели доцільність застосування цих технологій під час навчання у спеціальних закладах дітей з різними нозологіями. Утім узагальнені результати аналізу останніх досліджень, представлені у наукових публікаціях, свідчать про недостатню вивченість проблеми використання інформаційно-комунікаційних технологій у роботі 3 розумово відсталими учнями допоміжної школи.

Метою статті $\epsilon$ виявлення прогалин у розвитку інформатизованого середовища в межах спеціальної школи і визначення перспектив подальших наукових досліджень у цій галузі.

\section{2. РЕЗУЛЬТАТИ ДОСЛІДЖЕННЯ}

На сучасному етапі розвитку людства проблема використання сучасних інформаційно-комунікаційних, зокрема, комп'ютерних i хмарних, технологій $\epsilon$ надзвичайно важливою для нашої країни, зокрема, для системи освіти. Актуальність дослідження проблеми впровадження IКТ у систему спеціальної освіти обумовлена модернізацією навчального середовища, де одним із пріоритетних завдань $\epsilon$ підвищення ефективності навчально-виховної і корекційно-розвивальної роботи 3 розумово відсталими дітьми.

Слід зазначити, що інформатизацію спеціальної освіти можна розглядати як складову процесу розвитку інформаційного суспільства. Без підготовки педагогічного персоналу до впровадження новітніх інформаційних технологій у їхню професійну діяльність, розв'язання проблеми створення інформатизованого середовища в межах спеціальної школи не уявляється можливим. Останнім часом вирішенню цього питання приділяється значна увага під час формування професійного потенціалу майбутніх фахівців. До переліку нормативних навчальних дисциплін, за якими здійснюється підготовка майбутніх корекційних педагогів, включено курс «Інформаційні технології та технічні засоби корекційного навчання». Це сприяє підготовці вчителя нового типу, який вільно володіє комп'ютерними технологіями.

Аналіз наукової літератури з теми дослідження дозволив встановити, що науковці вивчають можливості застосування IКТ в освіті. Серед цих праць можна визначити ті, що присвячені застосуванню: ІІТ $\mathrm{i}$ веб-технологій у роботі адміністрації i педагогічного персоналу навчального закладу i мультимедійних засобів під час навчального процесу (А. М. Висоцька, Л. А. Карташова, О. Є. Кравчина, О. П. Пінчук, М. О. Синиця, О. Г. Смолянінова та ін.); комп'ютерно орієнтованих засобів навчання (Р. С. Гуревич, Ю. О. Жук та ін.); комп’ютера в процесі розв’ язування навчальних задач (В. М. Добряги, В. М. Симонова, В. А. Лецко та ін.). Слід зазначити, що наукові праці $з$ цієї проблематики переважно спрямовані на з'ясування можливостей застосування інформаційних технологій у роботі 3 дітьми 3 типовим розвитком (y cmammi мu використовуємо термін «типовий розвиток» стосовно осіб з нормальним розвитком, у них немає психофізичних порушень - Д. Т.).

Аналіз змісту наукових публікацій 3 проблеми дослідження у спеціальній педагогіці дозволив дійти висновку, що використання інформаційних технологій розглядається у кількох напрямах, серед яких ми виокремили такі: 1) застосування 
інформаційних технологій під час підготовки вчителів-дефектологів; 2) обгрунтування доцільності застосування IКТ в роботі з учнями 3 психофізичними порушеннями; $3)$ упровадження нових інформаційних технологій у навчальний процес як одного 3 шляхів удосконалення опанування учнями змісту освіти і контролю за якістю їх знань; 4) застосування комп'ютерних технологій як засобу корекційної роботи i засобу корекції вад дітей з психофізичними порушеннями.

Отже, у галузі спеціальної педагогіки можна систематизувати наукові дослідження і публікації за їх проблематикою і названими вище напрямами:

1. І. Федоренко досліджував проблему підготовки майбутніх учителівдефектологів до використання новітніх комп'ютерних технологій у процесі корекційного навчання [23];

2. обгрунтування доцільності застосування ІКТ у системі спеціальної освіти:
a) А. Висоцька, О. Гончарова, О. Кукушкіна, М. Малофеєв, В. Засенко, А. Колупаєва у своїх наукових публікаціях обгрунтовують доцільність і цінність використання комп'ютера в роботі 3 дітьми 3 вадами психофізичного розвитку;
б) В. Засенко, Б. Мороз, В. Овсяник вказують на доцільність використання інформаційних технологій в умовах спеціального й інклюзивного навчання дітей зі слухомовленнєвими порушеннями [19];
в) О. Василенко, М. Сметанський - використання комп'ютерних технологій у навчанні дітей з особливими потребами [3];

3. застосування комп'ютерних технологій у навчальній роботі 3 дітьми 3 психофізичними порушеннями:
a) І. Больших, В. Воронін, О. Кукушкіна, I. Федосова відзначали позитивний вплив застосування комп'ютерних технологій на мотивацію учнів до навчання;
б) Н. Кравець описувала особливості використання комп'ютерних технологій у процесі роботи розумово відсталих школярів з творами художньої літератури [12];

в) В. Синьов, А. Шевцов висвітлювали психолого-педагогічні проблеми використання віртуальних комп'ютерних середовищ, зокрема мережі Інтернет, у процесі соціальної реабілітації і корекційної медіаосвіти осіб 3 обмеженнями життєдіяльності. Науковці розглянули переваги i ризики використання Інтернет-середовища як форми організації реабілітаційного простору [21];

4. визначення ІКТ як одного із засобів корекційної роботи 3 дітьми (за нозологіями):

a) М. Шеремет, Г. Загурська розглядають роль і місце сучасних комп'ютерних технологій у логопедичній роботі [25];

б) О. Качуровська розглядає IT як новітній засіб корекції і розвитку мовлення учнів із тяжкими вадами мови [10];

в) В. Засенко, А. Колупаєва, Б. Мороз, В. Овсяник, О. Легкий доводять корекційно-розвивальну сутність застосування комп'ютерних технологій у роботі з дітьми з порушеннями слуху і зору [14; 19];

г) Л.А. Дітковська - у роботі 3 дітьми 3 порушеннями опорно-рухового апарату [6];

д) С. Гаврись, С. Григоренко, С. Миронова - використання комп’ютера у корекційному навчанні дітей з вадами інтелекту у допоміжній школі [5; 17].

Слід згадати, що серію досліджень ефективності використання комп'ютерної техніки в спеціальних школах розпочато з 1994 р. У працях О. Гончарової, 
О. Кукушкіної, М. Малофеєва, В. Засенка, А. Колупаєвої, Б. Мороза, В. Овсяник та ін. обгрунтовано доцільність і цінність використання комп'ютера як нового засобу навчання i засобу корекції вад дітей 3 обмеженими можливостями здоров'я. Науковцями визначено місце і роль комп'ютера на різних уроках та індивідуальних заняттях на всіх етапах шкільного навчання дітей з відхиленнями в розвитку, розкрито корекційну спрямованість уроків у комп'ютерному класі, визначено можливості корекції вад слуху.

Учені підкреслюють те, що інформаційні технології навчання допомагають учителю по-новому спроектувати навчальне середовище й оптимізують досягнення поставлених ним навчально-корекційних цілей уроку. Педагог отримує додаткові можливості для підтримки і спрямування розвитку особистості учня з обмеженими можливостями, творчого пошуку, організації їх спільної роботи [14, с. 36-37]. Вивчення стану практики в системі спеціальної освіти підтвердило цю тезу й дозволило констатувати те, що комп'ютерні технології все більше застосовуються в навчальному процесі. У цьому разі вчителі розглядають ці технології як засіб передавання знань розумово відсталим учням.

Проте, щоб забезпечити активну участь школярів з вадами інтелектуального розвитку в навчальному процесі з використанням IКТ, їх до цього слід завчасно підготувати. Запорукою успішності цього процесу $\epsilon$ попередньо сформована в учнів здатність роботи з/за комп'ютером.

Вивчення наукових публікації 3 проблеми формування інформаційної компетентності в осіб з типовим розвитком дозволив встановити, що під інформаційною компетентністю пропонується розуміти підтверджену здатність особистості задовольнити власні індивідуальні потреби і суспільні вимоги щодо формування загальних компетентностей людини в галузі інформатики. О. М. Спірін вказує, що загальні компетентності часто називають ключовими або базовими, а професійно-спеціалізовані компетентності часто називають предметними [22].

Отже, під час формування компетентності розумово відсталих учнів спеціальної школи у галузі інформатики мова має йти про рівень сформованості базової інформаційної компетентності. Професійно-спеціалізовані компетентності вони зможуть набувати під час опанування певної професії. Наприклад, у Росії є досвід підготовки розумово відсталих випускників до професії оператора комп'ютерного набору.

Утім, нині педагогічні колективи спеціальних шкіл в Україні стоять у витоків вирішення питання як і в якому обсязі формувати базовий рівень інформаційнокомунікаційної компетентності в розумово відсталих дітей. Ця проблема практики виникла унаслідок того, що під час обговорення проекту Концепції державного стандарту спеціальної освіти (1999р.) ідею впровадження предмету «Основи інформатики» у підготовку учнів допоміжної школи не було підтримано. На нашу думку, підставами для такого прагматичного підходу до вибору дисципліни слугував існуючий на той час стан практики: 1) недостатня підготовка у вищих начальних закладах майбутніх фахівців до застосування комп'ютерних технологій; 2) недостане забезпечення матеріально-технічної бази допоміжних шкіл, зокрема, відсутність у школі комп'ютерних класів; 3) недостатня доказова база щодо можливостей опанування розумово відсталими учнями комп'ютерної грамотності, що було обумовлено відсутністю наукових досліджень і практичного досвіду у цій галузі. Отже, на той час в обговоренні проекту вчителі допоміжних шкіл висловилися проти ідеї впровадження в практику спеціальної школи новітніх інформаційних технологій.

На сучасному етапі розвитку системи спеціальної освіти впровадженню ідеї застосування комп’ютерів у практиці допоміжних шкіл сприяє проведення наукових 
досліджень у галузі корекційної педагогіки. Науковці довели доцільність застосування комп'ютерів у роботі з дітьми із сенсорними порушеннями, а згодом і з учнями 3 вадами інтелектуального розвитку.

О. Легкий у своїх наукових дослідженнях доводить корекційно-розвивальну сутність застосування комп'ютерних технологій. Однак він зазначає, що впровадження ïх у роботу 3 дітьми 3 порушеннями зору має обов'язково підтримуватися певною системою допомоги, зокрема має бути визначено умови використання комп'ютера у спеціальних закладах для дітей з особливими потребами [14, с. 77].

Л. Дітковська отримала позитивні результати під час підготовки підлітків із дитячим церебральним паралічем до використання інформаційно-комунікаційних технологій [6].

Досліджуючи проблему надання логопедичної допомоги, О. Качуровська переконалася, що використання комп'ютерних програм у навчальному процесі шкіл сприяє індивідуально-диференційованому підходу, розвиває пізнавальну активність учнів із вадами мовленнєвого розвитку, підвищує мотивацію навчальної діяльності i, як наслідок - рівень знань. Утім, упровадження інформаційних технологій у навчальний процес можливе лише за умови створення якісних україномовних навчальнокорекційних програмних засобів, адаптованих до застосування в умовах спеціальної школи, розробки і суттєвого вдосконалення існуючих підходів щодо використання комп'ютерних технологій у навчальному процесі шкіл для дітей з вадами мовлення [10].

Вивчаючи специфіку впровадження комп'ютерних технологій учені І. Больших, В. Воронін, О. Кукушкіна, І. Федосова відзначали їх вплив на мотивацію до навчання в дітей з психофізичними порушеннями.

Н. Кравець зазначала особливості використання комп'ютерних технологій у процесі роботи розумово відсталих школярів з творами художньої літератури [12].

Результати досліджень І. Булаха, В. Бочарникової, О. Іваницького, І. Солух підтверджують ефективність використання тестуючих комп'ютерних систем під час визначення рівня засвоєння знань, умінь і навичок під час навчання учнів і студентів 3 типовим розвитком. Утім, результати практичної апробації цих систем під час роботи 3 учнями 3 вадами розумового розвитку, підтвердили доцільність їх застосування у спеціальній школі.

I. Холковська вважає, що у навчанні різних категорій дітей, які мають особливі освітні потреби, усе ширшого застосування набувають персональні комп'ютери. На думку І. Холковської, комп'ютерні засоби можна використовувати для розвитку навичок читання, письма, навчання математики, іноземної мови тощо. Комп'ютер може використовуватися як засіб контролю за діяльністю дітей, формування різних видів самоконтролю. Досвід використання комп'ютерної техніки у спеціальній освіті свідчить про позитивні результати як у навчальній діяльності, так і в корекції багатьох психофізичних особливостей розвитку дітей [24, с. 77].

Утім, усі науковці одностайно стверджують, що під час упровадження інформаційно-комунікаційних технологій у спеціальній школі необхідно враховувати особливості психіки дітей 3 особливими потребами, найперше ті, що можуть ускладнити роботу з технікою. Це, зокрема, підвищена втомлюваність, розпорошена увага, сповільнений темп сприймання, тривале входження у процес роботи.

Безумовно, особливості психофізичного розвитку розумово відсталих учнів обумовлюють специфіку їх навчання. Перед практиками постають питання: як і в якому обсязі формувати базовий рівень компетентності у розумово відсталих дітей; наскільки інтерес розумово відсталих учнів до комп'ютера підвищує їхню 
працездатність, сприяє зосередженню уваги і збільшує темп роботи. Ці питання визначають напрямки подальших наукових розвідок у спеціальній педагогіці.

Слід визначити ще один із перспективних напрямів сучасних досліджень 3 кпровадження інформаційних технологій у систему освіти, який може стати в нагоді під час організації діяльності спеціальної школи — це проблема застосування хмарних технологій.

Хмарні технології (англ. cloud technologies) - це досить новий сервіс, що дозволяє віддалено використовувати засоби обробки і зберігання даних [16, с. 99-100]. Однією з основних переваг використання хмарних сервісів і платформ $є$ можливість доступу до необхідних даних у будь-якому місці й у будь-який час. В. Ю. Биков підкреслює, що головні концептуальні засади стратегії подальшої масштабної інформатизації освіти мають базуватися на концепції застосування хмарних обчислень як альтернативи [1]. Питання використання хмарних технологій в освіті широко висвітлюють у своїх працях такі дослідники, як В. Борисов, О. Г. Кузьминська, Л. А. Карташова, С. Г. Литвинова, Н. В. Морзе, М. П. Шишкіна та ін. [2; 9; 16].

Вивчення стану практики довело, що нині можна виокремити кілька напрямів застосування хмарних сервісів у спеціальному навчальному закладі. 3'ясовано, що ця технологія використовується під час: управління навчальним закладом, організації методичної роботи; реалізації навчального процесу; роботи з громадськістю і батьками; самопрезентації і самоосвіти педагогічного персоналу та ін. Установлено, що в системі спеціальної освіти, як і загалом в освіті, найбільш застосованими є сервіси Google i Microsoft.

Нині веб-технології, зокрема хмарні технології, дозволяють інформації про організацію і результати навчання і виховання учнів спеціальної школи подолати існуючі бар'єри: географічні, технологічні, соціальні. Учителі надають методичні рекомендації і поради, дублюють домашні завдання для учнів спеціальної школи 3 певного предмету та інше, розміщуючи їх у «хмарі» - мережі Інтернет на сайтах, що належать до цієї «хмари».

Зберігаючи інформацію у «хмарі», педагоги розраховують на те, що учні і їхні батьки мають доступ до них у будь-який зручний для них час. Упродовж семестру в роботі з батьками вчителі застосовують такий прийом як доведення до їх відома успішності навчання (оцінок) учнів шляхом розміщення на сайті, який закритий для загального використання, з авторизованим доступом для певного кола користувачів.

Принагідно зазначимо, що на сайтах спеціальних навчальних закладів розміщується інформація, створена за допомогою засобів Microsoft Office 365: електронні портфоліо педагогів, відомості про успіхи учнів, віртуальні кабінети і вчительські, загальні дані про діяльність школи та ін.

Нині, під час створення віртуальних кабінетів будь-якого вчителя навчального закладу, можна спиратися на результати проведених у цьому напрямі наукових досліджень. Так, питання організації віртуальної вчительської засобами Google-site вивчалося Л. В. Рождественською [7; 20]; питання використання засобів Microsoft Office 365 для організації віртуального кабінету вчителя-предметника, віртуальної вчительської загальноосвітнього навчального закладу досліджувалося С. Г. Литвиновою [15].

Необхідно зазначити, що сучасні ідеї щодо застосування комп'ютера у школі викладено у «Концепції Програми інформатизації загальноосвітніх навчальних закладів, комп'ютеризації сільської школи» (автори Огнев'юк В. О., Биков В. Ю., Жалдак М. І. та ін.) [11]. Визначимо, що за В. Ю. Биковим ІКТ-навчання - «це комп'ютерноорієнтована складова педагогічної технології, яка відображає деяку формалізовану модель певного компоненту змісту навчання і методики його подання у 
навчальному процесі, що представлена у цьому процесі педагогічними програмними засобами і передбачає використання комп'ютера, комп'ютерноорієнтованих засобів навчання i комп'ютерних комунікаційних мереж для розв'язування дидактичних завдань або їх фрагментів» [1, с. 141].

Утім, застосування хмарних технологій в управлінській і педагогічній діяльності спеціальної школи залишається недостатньо розкритим. На нашу думку, перспективним напрямом наукових досліджень у галузі спеціальної освіти є розробка шляхів застосування хмарних технологій як інструмента створення інформаційного середовища взаємодії учасників освітнього процесу. Слід підкреслити, що застосування хмарних технологій в освіті передбачає здатність педагогічних працівників до використання цих ресурсів у професійній діяльності. Це означає, що дослідження змісту підготовки фахівців до застосування хмарних технологій у навчальному середовищі спеціальної школи є актуальним.

\section{3. ВИСНОВКИ ТА ПЕРСПЕКТИВИ ПОДАЛЬШИХ ДОСЛІДЖЕНЬ}

Початок XXI ст. характеризується посиленням процесів глобалізації. Власне глобалізація торкнулася всіх сторін суспільного життя, у тому числі й розвитку інформаційного середовища. Глобалізаційні процеси вплинули на розвиток інформаційного суспільства в Україні взагалі, і в системі освіти, зокрема.

Вивчення проблеми розвитку інформаційного середовища на інституціональному рівні дозволило виявити прогалини щодо впровадження інформаційно-комунікаційних технологій у систему спеціальної освіти. До них ми віднесли недостатнє вивчення науковцями проблем: 1) застосування веб-технологій у професійній діяльності адміністрації і педагогічного персоналу спеціальної школи; 2) підготовки фахівців до застосування хмарних технологій у навчальному середовищі спеціальної школи; 3) застосування хмарних технологій як інструмента створення інформаційного середовища взаємодії учасників освітнього процесу; 4) упровадження нових інформаційних технологій у навчальний процес як одного із шляхів удосконалення опанування учнями 3 порушеннями психічного та(або) фізичного розвитку змісту освіти і контролю за якістю їхніх знань; 5) застосування комп'ютерних технологій як засобу корекційної роботи i засобу корекції вад дітей 3 різними нозологіями; 6) формування базового рівня компетентності розумово відсталих учнів у галузі інформатики.

Отже, упровадження сучасних інформаційних технологій у діяльність спеціальної школи має багато перешкод, а, отже, потребує поглибленого вивчення й обгрунтування. Об’єктним полем цих досліджень мають бути сучасні інформаційно-комунікаційні технології, предметним - процес розвитку інформатизованого середовища на рівні спеціальної школи.

\section{СПИСОК ВИКОРИСТАНИХ ДЖЕРЕЛ}

1. Биков В. Ю. Моделі організаційних систем відкритої освіти : монографія / В. Ю. Биков. - К. : Атіка, 2008. - 684 с.

2. Борисов В. Полікультурне освітнє середовище як об'єкт соціально-педагогічного дослідження [Електронний ресурс] / В. Борисов, А. Гризоглазова. - Режим доступу : http://archive. nbuv.gov.ua/portal/soc_gum/gnvp/2011_58_3/25.pdf.

3. Василенко О. М. Використання комп'ютерних технологій у навчанні дітей з особливими потребами / О. М. Василенко, М. І. Сметанський // Актуальні проблеми комп'ютерних технологій 
(АПКТ 2008) : зб. наук. пр. за матеріалами II Всеукр. наук.-техн. конф., 24 квіт. 2008 р. Хмельницький : ХНУ, 2008. - Т. 1. - С. 50-55.

4. Висоцька А. М. Медіаосвіта як напрям навчально-виховного процесу в дошкільних та загальноосвітніх навчальних закладах / А. М. Висоцька // Наукові записки. Серія: Педагогіка. 2013. 一 № 3. - С. 70-73.

5. Гаврись С. Інформаційні технології у навчальній діяльності учнів допоміжної школи / С. Гаврись, Є. Григоренко // Дефектолог : газета. - 2009. - № 11. - С. 18-20.

6. Дітковська Л. А. Підготовка підлітків із дитячим церебральним паралічем до використання інформаційно-комунікаційних технологій : автореф. дис ... канд. пед. наук : 13.00 .03 / Л. А. Дітковська. - К., 2012 . - 20 с.

7. Дневник конференции. 10 шагов информатизации: призрак виртуальной учительской [Електроннй $\quad$ ресурс]. http://edugalaxy.intel.ru/index.php?automodule=blog\&blogid=8\&showentry=3664. — Назва з екрану.

8. Закон України «Про Основні засади розвитку інформаційного суспільства в Україні на 2007-2015 роки» [Електронний ресурс] / НАУ-Online Відомості Верховної Ради України (ВВР). — 2007. №12. — ст.102. — Режим доступу : http://zakon.nau.ua/doc/?uid=1131.142.0.

9. Карташова Л. А. Система навчання інформаційних технологій майбутніх вчителів суспільногуманітарних дисциплін : монографія / Л. А. Карташова. - Луцьк, 2011. — 264 с.

10. Качуровська О. Новітні засоби корекції та розвитку мовлення учнів із тяжкими вадами мови / О. Качуровська // Дефектологія. - 2006. - № 2. - С. 46-49.

11. Концепція Програми інформатизації загальноосвітніх навчальних закладів, комп'ютеризації сільської школи / Огнев’юк В. О., Биков В. Ю., Жалдак М. І. та ін. // Комп’ютер у школі та сім’ї. - 2000. — № 3(11). - С. 3-10.

12. Кравець Н. Використання комп'ютерних технологій у процесі роботи розумово відсталих школярів 3 творами художньої літератури / Н. Кравець // Особлива дитина. — № 1 (69). — 2014. — C. 28-37.

13. Кравчина О. Є. Управлінські інформаційні мережі в системі загальної середньої освіти / О. С. Кравчина // Інформаційні технології і засоби навчання. — 2009. — № 6 (14). — Режим доступу до журналу : http://www.ime.edu-ua.net/em.html.

14. Легкий О. Корекційні можливості застосування комп’ютера у спеціальній школі / О. Легкий // Дефектологія. - 2002. - № 1. - С. 36-39.

15. Литвинова С. Г. Методика використання технологій віртуального класу вчителем в організації індивідуального навчання учнів : автореф. дис. ... канд. пед. наук : спец. 13.00.10 "Інформаційнокомунікаційні технології в освіті" / С. Г. Литвинова. - К., 2011. - 22 с.

16. Литвинова С.Г. Хмарні технології в управлінні дошкільними навчальними закладами / С. Г. Литвинова // Информационно-компьютерные технологии в экономике, образовании и социальной сфере. Выпуск 8. - Симферополь : ФЛП Бондаренко О.А., 2013. - С. 99-101.

17. Миронова С. П. Використання комп'ютера у корекційному навчанні дітей 3 вадами інтелекту / С. П. Миронова // Дефектологія. — 2003. - №3. - С. 41-44.

18. Морзе Н. В. Як навчати вчителів, щоб комп'ютерні технології перестали бути дивом у навчанні? / Н. В. Морзе // Комп’ютер у школі та сім’ї. — № 6 (86). - 2010. — С. 10-14.

19. Мороз Б. С. К вопросу о внедрении компьютерной технологи в специальное обучение детей с особыми образовательными потребностями / Б. С. Моро3, В. П. Овсяник // Дидактичні та соціально-психологічні аспекти корекційної роботи у спеціальній школі : наук.-метод. зб. - К., 2009. - C. 188-194.

20. Рождественська Л. В. Мастер-класс: Информатизация школы в 10 шагах [Электронный ресурс]. Режим доступа : https://edugalaxy.intel.ru/conf/baseline/capplication/view/1. - Назва з екрану.

21. Синьов В. М. Потенціал віртуального комп'ютерного середовища в аспекті корекційної медіаосвіти і соціальної реабілітації осіб з обмеженнями життєдіяльності / В. М. Синьов, А. Г. Шевцов // Зб. стат. методологічного семінару «Медіаосвіта в Україні: наукова рефлексія викликів, практик, перспектив» (3 квітня 2013 р. м. Київ). - К., 2013. - С. 89-99.

22. Спірін О. М. Інформаційно-комунікаційні та інформатичні компетентності як компоненти системи професійно-спеціалізованих компетентностей вчителя інформатики [Електронний ресурс] / О. М. Спірін // Інформаційні технології і засоби навчання. - 2009. - № 5 (13). - Режим доступу до журналу : http://www.ime.edu-ua.net/em.html. 
23. Федоренко $\quad$ I. B. Підготовка майбутніх вчителів-дефектологів до використання новітніх комп'ютерних технологій у процесі корекційного навчання : автореф. дис. ... канд. пед. наук : спец. 13.00.03 «Корекційна педагогіка» / І. В. Федоренко. - К., 2011. — 21 с.

24. Холковська І. Л. Корекційна педагогіка / І. Л. Холковська. - Вінниця : ВДПУ ім. М. Коцюбинського, 2007. - 328 с.

25. Шеремет М.К. Сучасні комп’ютерні технології в логопедичній роботі / М. К. Шеремет, Г. Загурська // Педагогіка та методики: спеціальні : зб. наук. праць / Редкол. В. І. Бондар [та ін.] ; Нац. пед. ун-т ім. М. П. Драгоманова. - К., 2001. — С. 183-192.

Матеріал надійшов до редакиї 13.03.2015 p.

\title{
РАСПРОСТРАНЕНИЕ ИДЕЙ ВНЕДРЕНИЯ ИНФОРМАЦИОННО- КОММУНИКАЦИОННЫХ ТЕХНОЛОГИЙ В СИСТЕМУ СПЕЦИАЛЬНОГО ОБРАЗОВАНИЯ
}

\section{Дегтяренко Татьяна Николаевна}

доцент, доктор педагогических наук, профессор кафедры коррекционного и инклюзивного образования Сумской государственный педагогический университет имени А. С. Макаренко, г. Сумы, Украина t.dehtyarenko@gmail.com

\begin{abstract}
Аннотация. В статье исследованы некоторые аспекты внедрения в систему специального образования идей использования современных информационных технологий. Освещаются направления современных научных исследований в специальной педагогике по проблеме внедрения информационных технологий. Рассмотрены теоретические и практические достижения в использовании компьютерных и облачных технологий на институциональном уровне. Установлено сущность и возможности развития информатизированной среды в пределах специальной школы и непосредственно возможности использования новейших информационных технологий при обучении умственно отсталых детей. Обоснована целесообразность формирования базового уровня компетентности умственно отсталых школьников в области информатики.

Определены перспективы дальнейших научных исследований в этой области. Указано, что их предметным полем должен стать процесс развития информатизированной среды на уровне специальной школы.
\end{abstract}

Ключевые слова: умственно отсталые ученики; специальное образование; информационные технологии; компьютерные технологии; облачные технологии.

\section{DISTRIBUTION THE IDEAS OF IMPLEMENTATION OF INFORMATION AND COMMUNICATION TECHNOLOGIES IN THE SYSTEM OF SPECIAL EDUCATION}

Tetyana M. Dehtyarenko

docent, Doctor of pedagogical sciences, professor of the Department of correction and inclusive education Sumy State Pedagogical University named after A.S. Makarenko, Sumy, Ukraine t.dehtyarenko@gmail.com

\begin{abstract}
In the article the author has researched some aspects of ideas concerning implementation of modern information technologies in the system of special education. The author reviewed the directions of modern scientific researches in special pedagogy on the issue of implementation of information technologies. The author has considered the theoretical and practical achievements in the use of computer and cloud technologies at the institutional level. There has been defined the nature and possibilities of informatization environment development within the special schools and the possibilities for using the latest information technologies in mentally retarded children learning. The author has proved the expediency of forming a basic level of competence of the mentally retarded students in computer science.

The prospects for further scientific research in this area were defined. It was indicated that their
\end{abstract}


subject field should be a process of informatization environment development at the level of special school.

Keywords: mentally retarded pupils; special education; information technologies; computer technologies; cloud technologies.

\section{REFERENCES (TRANSLATED AND TRANSLITERATED)}

1. Bykov V. Yu. Models of the open education organizational systems: Monograph / V. Yu. Bykov. - K. : Atika, 2008. - 684 s. (in Ukrainian).

2. Borysov Multicultural learning environment as an object of socio-pedagogical research [online] / V. Borysov, A. Hryzohlazova. - Available from : http://archive. nbuv.gov.ua/portal/soc gum/gnvp/2011_58_3/25.pdf (in Ukrainian).

3. Vasylenko O. M. The use of computer technology in teaching children with special needs // Aktual'ni problemy komp'yuternyx texnolohij (APKT 2008) : zb. nauk. pr. za materialamy II Vseukr. nauk.-texn. konf., 24 kvit. 2008 r. - Xmel'nyc'kyj : XNU, 2008. — T. 1. - S. 50-55. (in Ukrainian).

4. Vysoc'ka A. M. Media Education as the direction of the educational process in preschool and secondary schools / A. M. Vysoc'ka // Naukovi zapysky. Seriya: Pedahohika. — 2013. — № 3. — S. 70-73. (in Ukrainian).

5. Havrys' S. Information technology in the training of students at a special school / S. Havrys', Ye Hryhorenko // Defektoloh : hazeta. — 2009._— № 11. — S. 18-20. (in Ukrainian).

6. Ditkovs'ka L. A Preparing adolescents with cerebral palsy to use information and communication technologies : avtoref. dys ... kand. ped. nauk: 13.00.03 / Lesya Anatoliyivna Ditkovs'ka. — K., 2012 . — 20 s. (in Ukrainian).

7. Diary of the conference. 10 steps of informatization: virtual ghost of teachers' room [online]. Available from: http://edugalaxy.intel.ru/index.php?automodule=blog\&blogid $=8 \&$ showentry=3664 Nazva z ekranu. (in Russian).

8. Law of Ukraine «On the Basic Principles of Information Society in Ukraine in 2007-2015» [online] / NAU-Online Vidomosti Verxovnoyi Rady Ukrayiny (VVR). — 2007. — №12. — St.102. — Available from : http://zakon.nau.ua/doc/?uid=1131.142.0 (in Ukrainian).

9. Kartashova L. A. System of information technology training for future teachers of social and humanitarian sciences : monograph / L. A. Kartashova. — Luc'k, 2011. — 264 s. (in Ukrainian).

10. Kachurovs'ka O. New correction tools and language development of students with severe disabilities of speech / O. Kachurovs'ka // Defektolohiya. — 2006. — № 2. — S. 46-49. (in Ukrainian).

11. Concept of the program of informatization of secondary schools, computerization of village schools / Ohnev’yuk V. O., Bykov V. Yu., Zhaldak M. I. ta in. // Komp’yuter u shkoli ta sim’yi . — 2000. — № 3(11). - S. 3-10.

12. Kravec' N. The use of computer technology in the process of work with mentally retarded students using literature / N. Kravec' // Osoblyva dytyna. — № 1 (69). — 2014. - S. 28-37 (in Ukrainian).

13. Kravchyna O. Ye. Management information networks in general secondary education // Informacijni texnolohiyi i zasoby navchannya. - 2009. - № 6 (14). - Rezhym dostupu do zhurnalu: http://www.ime.edu-ua.net/em.html.12 (in Ukrainian).

14. Lehkyj O. Corrective possibility of using a computer in a special school / O. Lehkyj // Defektolohiya. 2002. — № 1. - S. 36-39 (in Ukrainian).

15. Lytvynova S. H. Methods of using technology of virtual classroom by teacher in organizing of individual student teaching : avtoref. dys. ... kand. ped. nauk : spec. 13.00.10 «Informacijno-komunikacijni texnolohiyi v somite» / S. H. Lytvynova. - K., 2011. - 22 s. (in Ukrainian).

16. Lytvynova S. H. Cloud technologies in managing pre-school establishments / S. H. Lytvynova // Ynformacyonno-komp'yuternыe texnolohyy v эkonomyke, obrazovanyy y socyal'noj sfere Vыpusk 8. Symferopol' : FLP Bondarenko O. A., 2013. - S. 99-101. (in Ukrainian).

17. Myronova S. P. Using your computer in correctional education of children with disabilities in intelligence / S. P. Myronova // Defektolohiya. — 2003. — №3. - S. 41-44 (in Ukrainian).

18. Morze N. V. How to train teachers to not make computer technologies be a miracle in education? / N. V. Morze // Komp’yuter u shkoli ta sim’yi. — № 6 (86). — 2010. — S. 10-14 (in Ukrainian).

19. Moroz B. S. On the question of the introduction of computer technology in special education for children with special educational needs / B. S. Moroz, V. P. Ovsjanik // Didaktichni ta social'no-psihologichni 
aspekti korekcijnoï roboti u special'nij shkoli : nauk.-metod. zb. - K., 2009. — S. 188-194 (in Ukrainian).

20. Rozhdestvens'ka L. V. Master Class: Informatization of schools in 10 steps [online]. — Available from : https://edugalaxy.intel.ru/conf/baseline/capplication/view/1. — Nazva z ekranu. (in Russian).

21. Syn'ov V. M. Potential of virtual computer environment in terms of correctional media education and social rehabilitation of the disabled persons / V. M. Syn'ov, A. H. Shevcov // Zb. stat. metodolohichnoho seminaru «Mediaosvita v Ukrayini: naukova refleksiya vyklykiv, praktyk, perspektyv», 3 kvitnya 2013 r. m. Kyyiv). - K., 2013. - S. 89-99 (in Ukrainian).

22. Spirin O. M. Informational- communication and information competence as system components of professional and specialized competencies of computer science teacher [online] / O. M. Spirin // Informacijni texnolohiyi i zasoby navchannya. — 2009. — № 5 (13). — Available from: http://www.ime.edu-ua.net/em.html (in Ukrainian).

23. Fedorenko I. V. The training of future teachers-defectologists to use the latest computer technology in correctional education : avtoref. dys. ... kand. ped. nauk : spec. 13.00.03 «Korekcijna pedahohika»/ I. V. Fedorenko.—K., 2011. — 21 s. (in Ukrainian).

24. Xolkovs'ka I. L. Correctional pedagogy / I. L. Xolkovs'ka. - Vinnycya : VDPU im. M. Kocyubyns'koho, 2007. - 328 s. (in Ukrainian).

25. Sheremet M. K. Modern computer technology in speech therapy work / M.K. Sheremet, H. Zahurs'ka // Pedahohika ta metodyky: special'ni : zb. nauk. prac' / Redkol. V. I. Bondar [y dr.] ; Nac. ped. un-t im. M. P. Drahomanova. — K., 2001. — S. 183-192 (in Ukrainian). 